\title{
Alternative equity financing instruments for entrepreneurial ventures: a bibliometric analysis of research in the last three decades
}

\author{
Carmelo Reverte* and Rosa Badillo
}

This study aims to review scientific research in business economics related to entrepreneurial equity financing carried out in the last three decades (1984-2017) using a bibliometric analysis. To this end, 1321 documents on this topic were extracted from the Web of Science database and sorted according to the following perspectives: number of publications per year, the most cited articles, most eminent authors, journals with the highest citation per article, and countries with the highest productivity. Our research also provides clusters based on a co-occurrence analysis of keywords in order to identify the major themes investigated. Our results can be used to improve our understanding of the entrepreneurial equity financing field and identify promising research areas to further explore in the future.

Keywords: Bibliometrics, business angels, citation analysis, equity crowdfunding, entrepreneurship, venture capital.

THE critical role played by high-growth-potential startups in fostering employment generation, productivity growth and radical innovations is widely recognized ${ }^{1}$. However, startups have traditionally faced difficulties in accessing financial resources, resulting in the so-called financing gap problem. The lack of collateral and sufficient internal cash flow, as well as the presence of information asymmetries and agency problems, are the main causes underlying their barriers to accessing debt finance ${ }^{2,3}$. In response to these financial constraints faced by entrepreneurs and high-tech firms, governments around the world have tried to overcome this 'financing gap' by promoting the seed and early stage market. This has been done through the support of alternative equity financing schemes such as venture capital (VC), business angels (BAs) and, more recently, equity crowdfunding.

Despite growing interest in this topic, analysis on the status of entrepreneurial equity financing is scarce ${ }^{4}$. In this context, the aim of this study is to close this gap by performing a bibliometric analysis of entrepreneurial equity financing research with the intention of detecting the most frequently occurring themes and also identifying promising avenues for future research.

Carmelo Reverte and Rosa Badillo are in the Department of Accounting and Finance, Technical University of Cartagena, c/Real, 3, E-30201 Cartagena, Spain.

*For correspondence. (e-mail: carmelo.reverte@upct.es)
Bibliometric studies are gaining increasing attention in literature due to the growing need for analysing large volumes of information. Recent examples in the field of business economics include López-Fernández et al. ${ }^{5}$ on entrepreneurship and family firm research, Albort-Morant and Ribeiro-Soriano ${ }^{6}$ on business incubators, Dzikowski ${ }^{7}$ on born global firms and Hausberg and Korreck ${ }^{8}$ on business incubators and accelerators.

This study includes a bibliometric analysis based on 1321 pieces of research on entrepreneurial equity financing published during 1984-2017, retrieved from the Web of Science database. Specifically, we have focused on the three most studied equity finance instruments for earlystage ventures (i.e. VC, BAs and equity crowdfunding). Quantitative data are used to measure the productivity of authors and journals based on the number of publications, while qualitative indicators are used to evaluate the impact of authors, themes and journals from a citation-based perspective. A co-word occurrence analysis is employed in our study to identify the core areas of interest, an aspect unexplored to date in the entrepreneurial equity financing area. This latter type of content analysis is deemed to be particularly interesting as it provides an overview of the scientific field reducing the subjectivity inherent to traditional literature review processes.

Articles retrieved from the Web of Science are sorted according to the following items: number of publications per year, most cited articles, most eminent authors, 
journals with the highest citation per article and countries with the highest productivity.

\section{Entrepreneurial equity financing for startup firms}

The agency costs theory ${ }^{9}$ posits that information asymmetries between shareholders and managers are a major source of agency problems. Information asymmetries are exacerbated in entrepreneurial ventures as it is problematic for investors to assess the potential value of high-tech startups. The low value of collateral (i.e. tangible assets) is an additional deterrent for debt providers to bear the high risk of investments in young entrepreneurial ventures ${ }^{10}$, which results in many entrepreneurial companies forgoing their growth opportunities when external financing is also required ${ }^{3,11}$.

Equity capital represents a good financing alternative for entrepreneurial ventures as collateral is not required. So far, entrepreneurial equity financing has mainly focused on VC due to the higher development of VC markets (especially, in the US) and their critical role in providing finance to entrepreneurial ventures.

VC firms raise funds from a set of limited partners (pension funds, insurance companies, etc.) and primarily invest in young firms with a high growth potential in return for an equity stake ${ }^{12}$. They not only provide financial resources, but also offer a bundle of value-adding activities by performing a 'coaching' function, that is, providing portfolio companies with management, strategy, financial, administrative and marketing support ${ }^{13-17}$. These financial intermediaries are able to reduce problems associated with information asymmetries in several ways. They perform a thorough screening process ${ }^{18-20}$ before the investment. They sign contracts to oversee and incentivize portfolio company managers ${ }^{21}$ and, finally, conduct a close monitoring and supervision of investee firms in the post-investment stage ${ }^{14,15,22,23}$. In addition, $\mathrm{VC}$ endorsement provides a sort of certification about the investees' quality to uninformed third parties ${ }^{24}$.

However, VC is only limited to a small subset of entrepreneurs as venture capitalists have become more risk-averse after the advent of the financial crisis and have tended to focus on later-stage investments. Thus, in order to help early-stage firms that are not yet attractive for venture capitalists, other forms of disintermediated equity financing have emerged in the last decade such as BAs and equity-crowdfunding, which allow entrepreneurial firms to raise funds directly from individual investors either offline (BAs) or online from internet users (crowdfunding).

BAs are gaining increasing popularity as equity capital providers for startup companies ${ }^{25}$. They are wealthy and experienced business people that invest their own personal money into young high-growth businesses in exchange for equity. They are located in a segment situated between informal (i.e. founders, family and friends) and formal $\mathrm{VC}$ investors ${ }^{26}$. In contrast to $\mathrm{VC}$ firms that are mainly focused on financial rewards, BAs have different motivations such as coaching and mentoring entrepreneurs. As a result, they attach more emphasis on the entrepreneur's characteristics in their investment appraisal relative to $\mathrm{VC}$ firms. In the last few years, BAs have increased their impact by forming networks ${ }^{27}$ and by structuring themselves into online platforms to invest collectively. It should be noted, however, that empirical research on BAs has been traditionally limited by the paucity of financial data given the relatively high opaqueness of this market and the generally narrow representativeness of survey-based samples ${ }^{25,28-30}$. As a consequence, contributions investigating the performance of angel-backed companies primarily rely on anecdotal or case-based evidence ${ }^{27,31,32}$.

Finally, equity crowdfunding has emerged in the last few years as an alternative form of entrepreneurial equity financing that has helped democratize the investment process by enabling the access to a higher number of potential investors. It is the process whereby people invest in an early-stage company in exchange for shares in that company. Equity crowdfunding is mainly focused on nascent entrepreneurial ventures that cannot access bank financing or do not need the larger amounts of money available from $\mathrm{VC}$ or $\mathrm{BAs}^{33}$. Research on this topic is still scarce due to the recent development and regulation of the equity crowdfunding market and the difficulty in gathering the data ${ }^{34}$. As long as emerging online platforms become more popular, this creates important research opportunities ${ }^{35-37}$.

To sum up, as pointed out by Cumming and Vismara ${ }^{38}$, entrepreneurial equity finance literature is largely segmented for reasons mainly related to data availability, which justifies the usefulness of our bibliometric analysis to determine the core areas of interest and provide some future research directions.

\section{Methodology}

\section{Bibliometric analysis}

Bibliometric analysis employs a quantitative approach to organize the scientific activity within a specific field in a transparent and systematic manner ${ }^{39}$. Among the main bibliometric techniques we can underscore two of them: performance analysis and science mapping. Performance analysis focuses on the publication performance of authors, journals and institutions, while science mapping is intended to explore into the dynamics of a research field along time, based on a co-citation analysis ${ }^{40}$.

\section{Choice of database}

This study uses the WoS database to retrieve documents from 1984 to 2017. As all the main journals covering 
entrepreneurial equity financing issues are included in the WoS database we use the latter as the source for our bibliometric analysis (like other authors such as AlbortMorant and Ribeiro-Soriano ${ }^{6}$, Dzikowski ${ }^{7}$ and Hausberg and $\mathrm{Korreck}^{8}$ ). WoS is the most popular scientific research database worldwide and includes those journals with the highest impact. We chose 1984 as the starting year because the VC literature began to gain a foundation by the mid-1980s with the seminal paper by Tyebjee and Bruno $^{20}$. The keywords included in the search were 'venture capital', 'venture capitalist(s)', 'business angels', 'angel investors', 'angel investment' and 'equity crowdfunding' utilizing the Boolean operator 'or' in the topic field. Moreover, since our focus is on the business economics area, we chose as an additional filter, 'research area $=$ Business Economics', yielding 1321 documents . The search was conducted during the first week of February 2018.

\section{Indicators}

The current study uses both quantity and quality indicators ${ }^{41}$. The first ones (usually referred to as activity indicators) are focused on the productivity of journals, researchers and institutions based on the number of publications. The second ones (called first and second generation relation indicators) are aimed at measuring the frequency of citations of publications, authors or journals using author co-citation analysis (ACA) and co-word analysis (CA). Due to space limitations, we will focus on $\mathrm{CA}$ in this paper, which hinges on the analysis of keywords co-occurrences. This enables the depiction of the state-of-the-art in a specific field by means of the identification and classification of clusters in a matrix based upon their degree of development.

Following Castillo-Vergara et al. $^{42}$, two tools are employed in our analysis. The first one, VOSviewer, is a free software developed by Waltman and Van $\mathrm{Eck}^{43}$ for constructing and visualizating bibliometric networks. Specifically, network maps have been created taking into consideration the most cited journals and keywords.

The second program used is SciMAT, which provides a strategic diagram that depicts the detected clusters in a two-dimensional space based on density and centrality measures ${ }^{44,45}$. Given both measurements, research topics can be classified into four groups:

(i) Motor clusters (upper-right quadrant with high density and strong centrality - called 'motor themes'-). They represent topics that are important for the structuring of the field and are also well developed.

(ii) Highly developed and isolated clusters (upper-left quadrant with high density and low centralitycalled 'specialized themes'). These themes are well developed but are less important for the field. (iii) Emerging or declining clusters (lower-left quadrant with low density and low centrality - called 'emerging or disappearing themes'). They represent topics that are less developed and are of a lower importance; and

(iv) Basic and transversal clusters (lower-right quadrant themes with high centrality but low density - called 'transversal and general themes'). These topics, although not developed enough, are crucial for a research field.

\section{Results}

\section{Results of the activity indicators}

Regarding the number of publications per year, Figure 1 depicts the growing pattern of entrepreneurial equity financing in the last thirty years. The highest number of documents is concentrated from 2008 onwards, which can be attributed to the increasing critical role played by $\mathrm{VC}$ and BAs for financing young innovative companies due to their difficulties in raising external capital from banks in the post-2008 financial crisis period. Another reason is the progressive development of these financing instruments in markets other than the US, especially in Europe.

Table 1 shows the top authors based on the number of articles and citations per article. D. Cumming is the most prolific author with 30 publications, followed by $\mathrm{M}$. Wright with 23 and J. Lerner with 20. Looking at the number of citations per article, the first three authors are P. Gompers with 256.45, followed by J. Lerner with 149.1 and T. Hellman with 147.67.

Table 2 includes the 20 most cited publications based on Web of Science data. The most cited article is 'The structure and governance of venture-capital organizations' (1990) by W. A. Sahlman published in the Journal of Financial Economics with 777 citations. This paper explores the structure of VC firms, focusing on the VCinvestee firm relationship and the resulting agency

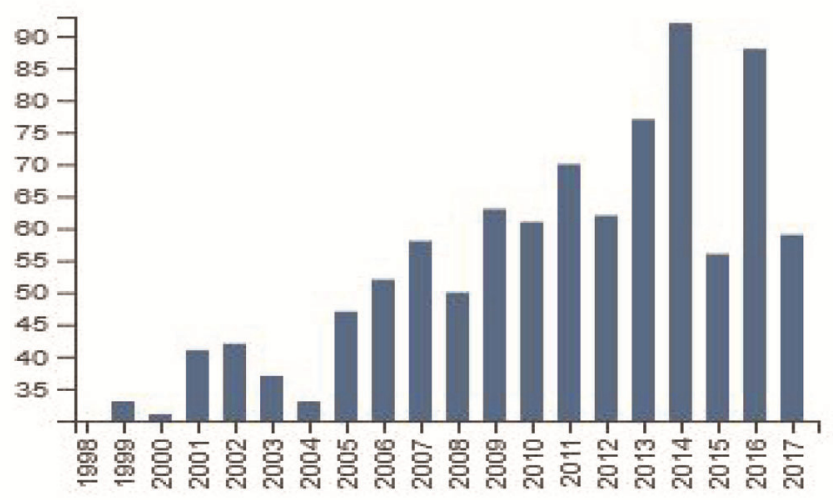

Figure 1. Number of documents per year. (Source: Web of Science.) 
problems and the contracts and operating procedures designed to mitigate them. The second most cited article is 'Venture capitalist certification in initial public offerings' (1991) by W. L. Megginson and K. A. Weiss published in the Journal of Finance with 737 citations. This paper documents the certification effect associated to VC backing in the context of IPOs. The third most cited article is 'Syndication networks and the spatial distribution of venture capital investments' (2001) by O. Sorenson and T. E. Stuart published in the American Journal of Sociology with 582 citations. This article reveals that VC investors have a strong tendency to invest in nearby startups and explains how the intrinsic characteristics of VC can justify these tendencies.

Table 3 identifies the most influential journals based on the number of papers published by each journal and the average number of citations per article. The data reveal that the Journal of Business Venturing has the highest number of articles (113), followed by Small Business Economics (44) and Entrepreneurship Theory and Practice (33). Regarding citations per article, the Journal of Finance is the first (223.67), followed by the Journal of Financial Economics (181.39) and the Journal of Business Venturing (58.25).

Figure 2 represents the citation network map of journals to classify them into clusters based on the citations among them. The weights of the nodes are represented by the size of the nodes and words. Those nodes with identical colour belong to a cluster whereas the distance

Table 1. Most prominent authors

\begin{tabular}{lccc}
\hline Authors & $\begin{array}{c}\text { Number of } \\
\text { publications }\end{array}$ & $\begin{array}{c}\text { Number of } \\
\text { citations }\end{array}$ & $\begin{array}{c}\text { Citations } \\
\text { per article }\end{array}$ \\
\hline D. Cumming & 30 & 1048 & 34.93 \\
M. Wright & 23 & 1144 & 49.74 \\
J. Lerner & 20 & 2982 & 149.1 \\
R. T. Harrison & 17 & 600 & 35.29 \\
C. M. Mason & 19 & 817 & 43.00 \\
S. Manigart & 12 & 635 & 52.92 \\
A. Schwienbacher & 11 & 240 & 21.82 \\
D. A. Shepherd & 11 & 824 & 74.91 \\
H. J. Sapienza & 11 & 1097 & 99.73 \\
A. L. Zacharakis & 11 & 661 & 60.09 \\
P. Gompers & 11 & 2821 & 256.45 \\
F. Bertoni & 10 & 211 & 21.10 \\
M. V. J. Maula & 10 & 203 & 20.30 \\
M. G. Colombo & 9 & 249 & 27.67 \\
M. Kenney & 9 & 436 & 48.44 \\
T. Hellmann & 9 & 1329 & 147.67 \\
O. Bengtsson & 8 & 39 & 4.88 \\
Y. Li & 8 & 175 & 21.88 \\
L. Grilli & 8 & 248 & 31.00 \\
D. Dimov & 8 & 256 & 32.00 \\
D. De Clercq & 8 & 317 & 39.63 \\
C. Keuschnigg & 8 & 499 & 62.38 \\
A. Lockett & 699 & 87.38 \\
\hline Sour & & &
\end{tabular}

Source: Own elaboration from Web of Science database. between two nodes captures the strength of the relationship between them; so a shorter distance means a stronger relationship. Consistent with the results shown in Table 3, Journal of Business Venturing, Small Business Economics and Entrepreneurship Theory and Practice journals have the highest node sizes. Five clusters are identified by VOSviewer. The first one is formed by the Journal of Business Venturing, Entrepreneurship Theory and Practice, Journal of Small Business Management and International Small Business Journal. Cluster 2 includes Journal of Financial Economics, Journal of Banking and Finance, Small Business Economics, Journal of Finance and Journal of Corporate Finance. Cluster 3 is formed by the International Journal of Technology Management and Research Policy. Cluster 4 includes Strategic Entrepreneurship Journal and Academy of Management Journal. Finally, Cluster 5 is composed of the Journal of Business Research and Technovation.

Table 4 shows the most influential countries based on the number of documents published by each country in the collection. The United States attains the first position with 564 documents, followed by the UK with 135 and Canada with 94, which is consistent with the higher development of the VC market in the US.

\section{Content analysis based on keywords co-occurrence}

Keywords co-occurrence analysis is based on the idea that a research field can be identified by the particular associations established between its keywords ${ }^{45}$. Unlike citation analysis, the co-words analysis does not penalize more recent studies. The keyword density visualization map was constructed using the VOSviewer software (see Figure 3). The larger (smaller) the number of items in the neighbourhood of a point and the higher (lower) the weights of the neighbouring items, the closer the colour is to red (blue). VOSviewer clearly identifies the keyword 'venture capital' as that with the highest frequency of occurrence, followed by 'entrepreneurship', 'initial public offerings', 'corporate venture capital', 'innovation' and 'business angels'.

Figure 4 depicts the strategic diagram corresponding to the whole period under analysis (1984-2017) where the sphere size represents the $h$-index of each cluster or theme while Table 5 shows the centrality and density values for each of them. Two motor themes are identified such as VC and initial public offerings (IPOs, hereafter). VC has the remarkably highest $h$-index (37), which is consistent with the prominent role of $\mathrm{VC}$ in entrepreneurial equity financing. In this regard, research has focused, among other aspects, on the role VC firms play in reducing financial constraints in investee firms ${ }^{11,46}$ and the impact of VC finance on several important aspects such as innovation $^{47}$, product time-to-market ${ }^{48}$, sales growth $^{49}$, productivity $^{50,51}$ and employment growth ${ }^{52-56}$. 
Table 2. Most cited publications

\begin{tabular}{|c|c|c|}
\hline Title & Journal & No. of citations \\
\hline The structure and governance of venture-capital organizations (Sahlman, 1990) & Journal of Financial Economics & 777 \\
\hline Venture capitalist certification in initial public offerings (Megginson and Weiss, 1991) & Journal of Finance & 737 \\
\hline $\begin{array}{l}\text { Syndication networks and the spatial distribution of venture capital investments } \\
\text { (Sorenson and Stuart, 2001) }\end{array}$ & American Journal of Sociology & 582 \\
\hline $\begin{array}{l}\text { Venture capital and the professionalization of start-up firms: empirical evidence } \\
\text { (Hellman and Puri, 2002) }\end{array}$ & Journal of Finance & 494 \\
\hline Assessing the contribution of venture capital to innovation (Kortum and Lerner, 2000) & Rand Journal of Economics & 462 \\
\hline $\begin{array}{l}\text { Venture capital and the structure of capital markets: banks versus stock markets } \\
\text { (Black and Gilson, 1998) }\end{array}$ & Journal of Financial Economics & 437 \\
\hline Venture capitalists and the oversight of private firms (Lerner, 1995) & Journal of Finance & 410 \\
\hline What do venture capitalists do? (Gorman and Sahlman, 1989) & Journal of Business Venturing & 405 \\
\hline The venture capital revolution (Gompers and Lerner, 2001) & Journal of Economic Perspectives & 390 \\
\hline Optimal investment, monitoring, and the staging of venture capital (Gompers, 1995) & Journal of Finance & 387 \\
\hline $\begin{array}{l}\text { The role of venture capital in the creation of public companies - evidence from the } \\
\text { going-public process (Barry, Muscarella, Peavy III and Vetsuypens, 1990) }\end{array}$ & Journal of Financial Economics & 359 \\
\hline A model of venture capitalist investment activity (Tyebjee and Bruno, 1984) & Management Science & 346 \\
\hline Grandstanding in the venture capital industry (Gompers, 1996) & Journal of Financial Economics & 338 \\
\hline What do entrepreneurs pay for venture capital affiliation? (Hsu, 2004) & Journal of Finance & 328 \\
\hline $\begin{array}{l}\text { The interaction between product market and financing strategy: the role of } \\
\text { venture capital (Hellman and Puri, 2000) }\end{array}$ & Review of Financial studies & 328 \\
\hline $\begin{array}{l}\text { The government as venture capitalist: the long-run impact of the SBIR program } \\
\text { (Lerner, 1999) }\end{array}$ & Journal of Business & 321 \\
\hline The syndication of venture capital investments (Lerner, 1994) & Financial Management & 299 \\
\hline Venture capitalists and the decision to go public (Lerner, 1994) & Journal of Financial Economics & 271 \\
\hline
\end{tabular}

Source: Own elaboration from Web of Science database.

Table 3. Most prominent journals

\begin{tabular}{lcrr}
\hline & $\begin{array}{c}\text { No. of } \\
\text { publications } \\
\text { (P) }\end{array}$ & $\begin{array}{c}\text { No. of } \\
\text { citations } \\
\text { Journal }\end{array}$ & \multicolumn{1}{c}{ C/P } \\
\hline Journal of Business Venturing & 113 & 6582 & 58.25 \\
Small Business Economics & 44 & 583 & 13.25 \\
Entrepreneurship Theory and Practice & 33 & 992 & 30.06 \\
Fortune & 30 & 5 & 0.17 \\
Journal of Corporate Finance & 21 & 564 & 26.86 \\
Research Policy & 21 & 1214 & 57.81 \\
Nature Biotechnology & 19 & 46 & 2.42 \\
Journal of Banking \& Finance & 18 & 735 & 40.83 \\
Journal of Finance & 18 & 4026 & 223.67 \\
Journal of Financial Economics & 18 & 3265 & 181.39 \\
Journal of Small Business Management & 18 & 268 & 14.89 \\
Strategic Entrepreneurship Journal & 18 & 158 & 8.78 \\
Academy of Management Journal & 17 & 589 & 34.65 \\
International Journal of Technology & 16 & 105 & 6.56 \\
$\quad$ Management & & & \\
Forbes & 14 & 1 & 0.07 \\
International Small Business Journal & 14 & 198 & 14.14 \\
Scientist & 14 & 4 & 0.29 \\
Technovation & 14 & 126 & 9.00 \\
Journal of Business Research & 13 & 156 & 12.00 \\
Journal of Management Studies & 13 & 520 & 40.00 \\
Harvard Business Review & 12 & 246 & 20.50 \\
Strategic Management Journal & 12 & 377 & 31.42 \\
\hline Sourc: Own eaboration fra Web of Scing & & & \\
\hline
\end{tabular}

Source: Own elaboration from Web of Science database.
As regards IPOs, they are the typical common exit strategy for $\mathrm{VC}$ firms at the time of divestment. One of the most cited papers in the $\mathrm{VC}$ field ${ }^{24}$ evidences that the presence of VCs in the issuing firms proves useful for decreasing the total costs of going public and maximizing the net proceeds of the IPO that accrues to the issuing firm, which is indicative of a sort of certification role provided by VCs. The other influential paper by Barry et $a l .{ }^{57}$ shows that the quality of $\mathrm{VC}$ monitoring services is valued by investors through lower underpricing for IPOs. Research has also focused on examining whether VCbacked firms are more likely to reach IPO more quickly and attain higher valuations than non-VC-backed firms ${ }^{58}$.

Figure 4 shows two transversal and general themes such as BAs and networks. Regarding BAs, as they reject most opportunities they receive and have different motivations with respect to VC firms; a strand of research has examined BAs' decision-making processes and the criteria used by them in investment appraisal ${ }^{59-61}$. As the 2008 financial crisis resulted in remarkable drops in both bank lending availability and VC, other studies have examined the behaviour of the angel market during the early years of the financial crisis ${ }^{62}$. More recently, research has examined the performance of angel-backed companies in terms of innovation and value creation ${ }^{30,63}$. 


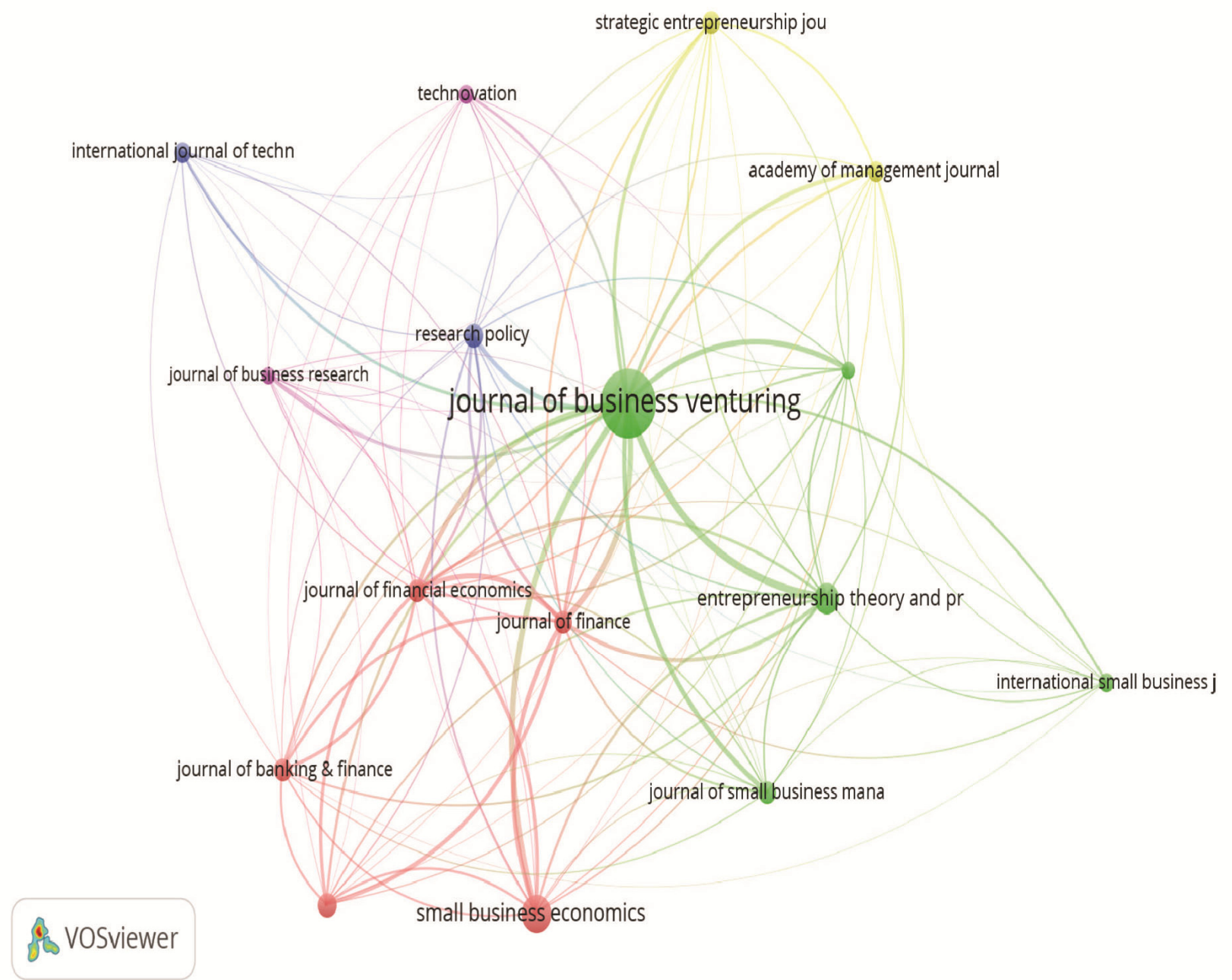

Figure 2. Citation journal map. (Source: VOSviewer.)

Table 4. Countries with the highest number of publications

\begin{tabular}{lc}
\hline Country & Number of publications \\
\hline USA & 564 \\
England & 135 \\
Canada & 94 \\
Germany & 83 \\
China & 59 \\
France & 53 \\
Italy & 46 \\
Belgium & 42 \\
The Netherlands & 40 \\
Switzerland & 36 \\
\hline
\end{tabular}

Source: Own elaboration from Web of Science database.

As for the other general theme (i.e. networks), they feature prominently in the VC industry for several reasons. Networks are useful for facilitating the sharing of information among VC firms, which can better guide the choice of investments when there is high uncertainty about the return potential and feasibility of investment projects. Moreover, as individual VC firms tend to have some kind of sectoral specialization, networking allows a portfolio diversification and an expansion of strategic alliance partners for their portfolio companies ${ }^{64}$. Finally, better-networked VCs have a higher fund performance and are more likely to obtain subsequent financing ${ }^{65}$. More recently, networks are also extending to BAs by providing online platforms in order to invest in high potential deal flow collectively ${ }^{27}$.

Another topic that also appears in the strategic diagram closely related to networks is syndication because VC syndication gives rise to coinvestment networks. Syndication has been widely used in the VC market as it eases the search for high-quality deal flow and increases the value added to investee companies ${ }^{65-67}$.

Finally, Silicon Valley and Corporate Venture Capital (CVC, hereafter) appear in Figure 4 as specialized themes. Silicon Valley accounts for a significant portion of the total VC investment in the US that benefits startups located in their proximity. In this respect, Zhang ${ }^{68}$ finds that their proximity to VC makes Silicon Valley startups 


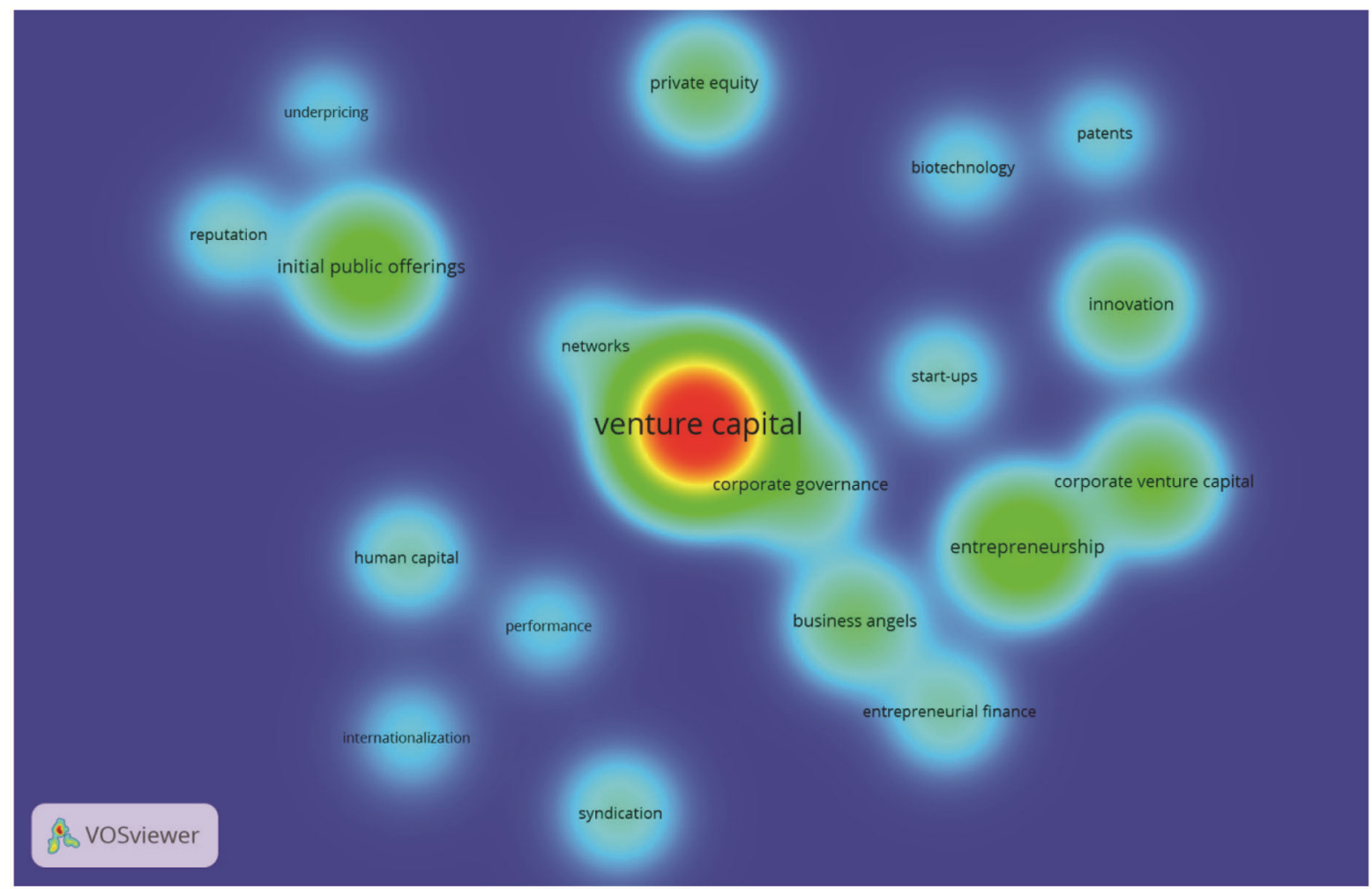

Figure 3. Density visualization map of keywords. (Source: VOSviewer.)

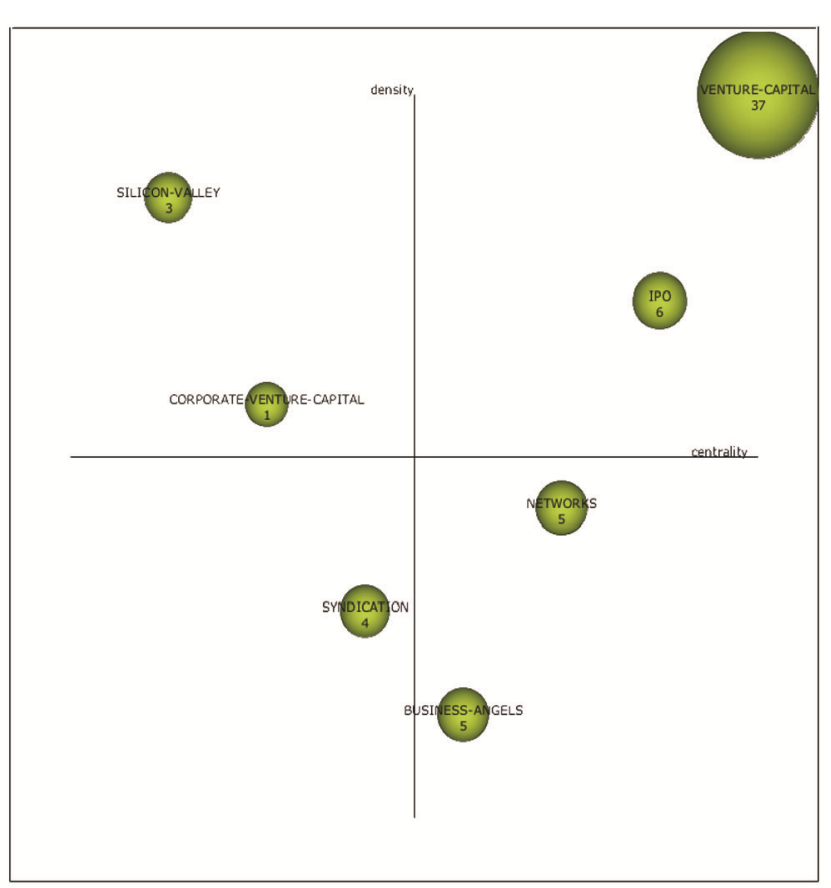

Figure 4. Strategic diagram (1984-2017). (Source: SciMAT.)

more likely to complete IPOs and also has a positive effect on the start-ups' employment and profitability.

As opposed to VC, CVC is the direct minority equity investment carried out by large and established compa- nies in promising ventures ${ }^{69}$. In contrast to VCs who are purely focused on financial returns, CVC firms are more guided by strategic benefits than by financial considerations. In this respect, research has documented that CVC provides strategic benefits to startup ventures, including access to tangible and intangible complementary resources that VC firms cannot provide ${ }^{70}$. Other studies have evidenced the role of CVC investing in fostering innovation and knowledge creation ${ }^{71,72}$, and in the provision of economically significant value to sponsoring firms ${ }^{73}$.

\section{Conclusions and research opportunities}

From the analysis carried out, we can infer that BA and networks are general themes that need further development. Additional studies on the contribution of BA to the development of new ventures are needed by examining BAs' impact on both the performance and the probability of survival of investee companies and the role of angel syndicates and their hands-on involvement. As most previous evidence is focused on the US and UK context, more studies about the internationalization of business angel research are needed in order to examine whether international differences in cultural, economic and legal dimensions (e.g. minority shareholders protection and economic and stock market development) affect angel investments and divestments ${ }^{74}$. Another promising area is 
the study of the BAs' decision-making processes as preliminary evidence shows that they are mainly based on heuristic-based reasoning and intuition beyond purely financial considerations ${ }^{75}$. Indeed, recent research $^{60,76}$ documents that the BAs' valuation approach does not adhere to the conventional protocols of financial analysis as it is mainly based on subjective information that emphasizes personal and informal over formal sources of information.

Another fruitful line of research is related to equity crowdfunding platforms as useful complements to angel investors in financing nascent ventures. Research on this topic is scarce so far due to the recent development and regulation of the equity crowdfunding market and the difficulty in gathering data. Potential future studies could address what determines investment decisions made by individuals in the crowdfunding market. In this regard, recent evidence ${ }^{77,78}$ shows the importance of information updates about the entrepreneur on both the number of investments made by the crowd and the funds received by the start-up. Prospective crowdfunding investors typically watch pitch videos and invest in online sites, which raises important questions about how they evaluate funding opportunities. It would be interesting to deepen our knowledge on how equity crowdfunding platforms screen ventures and apply due diligence services in order to mitigate adverse selection resulting from information asymmetries. However, the empirical evidence so far is based on single-country platforms. Thus, cross-national analyses are needed to see whether country-specific characteristics in regulations affect equity crowdfunding performance. Another interesting line of research would be to examine whether equity crowdfunding syndicates are able to further reduce information asymmetries and, thus, have a positive impact on the success of the campaign. Moreover, further research is needed on the demand for equity crowdfunding and its impact on startups ${ }^{79}$. In this respect, another interesting avenue for research would be to explore whether due diligence services provided not only affect the success of the crowdfunding campaign but also startups' success after the campaign.

All in all, the growth of funding alternatives available to entrepreneurs other than bank lending - such as BA

Table 5. Topics strategic map (1984-2017)

\begin{tabular}{lcl}
\hline Cluster & Centrality & Density \\
\hline Venture-Capital & 16.33 & 5.54 \\
IPO & 5.28 & 3.4 \\
Business Angels & 4.47 & 1.29 \\
Corporate Venture Capital & 2.37 & 1.81 \\
Networks & 4.6 & 1.46 \\
Silicon-Valley & 2.11 & 5.24 \\
Syndication & 4.41 & 1.38 \\
\hline
\end{tabular}

Source: Own elaboration from SciMAT software. and crowdfunding - has interesting implications when they are considered altogether. Most studies examine funding sources in an isolated way, but considering their interrelations is a promising research area. In this regard, recent research ${ }^{80}$ evidences that several attributes of angel and crowdfunded investments have a certification role for VC firms in their due diligence screening decisions and increase the probability of subsequent financing. Thus, further research should explore the several ways in which funding alternatives may complement together and their certification role for later-stage investors.

1. Criscuolo, C., Gal, P. N. and Menon, C., The Dynamics of Employment Growth: New Evidence from 18 Countries, OECD Science, Technology and Industry Policy Papers No. 14, OECD Publishing, Paris. 2014

2. Binks, M. R., Ennew, C. T. and Reed, G. V., Information asymmetries and the provision of finance to small firms. Int. Small Bus. J., 1992, 11(1), 35-46.

3. Carpenter, R. E. and Petersen, B. C., Capital market imperfections, high-tech investment, and new equity financing. Econ. J., 2002, 112, F54-F72.

4. Drover, W., Busenitz, L., Matusik, S., Townsend, D., Anglin, A. and Dushnitsky, G., Venture capital, corporate venture capital, angel investment, crowdfunding and accelerators: a review and roadmap of entrepreneurial equity financing research. J. Manage., 2017, 43(6), 1820-1853.

5. López-Fernández, M. C., Serrano-Bedia, A. M. and Pérez-Pérez, M., Entrepreneurship and family firm research: a bibliometric analysis of an emerging field. J. Small Bus. Manage., 2016, 54(2), 622-639.

6. Albort-Morant, G. and Ribeiro-Soriano, D., A bibliometric analysis of international impact of business incubators. J. Bus. Res., 2016, 69(5), 1775-1779.

7. Dzikowski, P., A bibliometric analysis on born global firms. $J$. Bus. Res., 2018, 85, 281-294.

8. Hausberg, J. P. and Korreck, S., Business incubators and accelerators: a co-citation analysis-based, systematic literature review. $J$. Technol. Transfer., 2018, forthcoming; https://doi.org/10.1007/ s10961-018-9651-y.

9. Jensen, M. C. and Meckling, W. H., Theory of the firm: managerial behavior, agency costs and ownership structure. J. Financ. Econ., 1976, 3, 305-360.

10. Berger, A. N. and Udell, G. F., The economics of small business finance: the roles of private equity and debt markets in the financial growth cycle. J. Bank Financ., 1998, 22, 613-673.

11. Bertoni, F., Ferrer, M. A. and Martí, J., The different roles played by venture capital and private equity investors on the investment activity of their portfolio firms. Small Bus. Econ. Group., 2013, 40, 607-633.

12. Gompers, P. and Lerner, J., The Venture Capital Cycle, Cambridge MA, MIT Press, 2006, 2nd edn.

13. Gorman, M. and Sahlman, W. A., What do venture capitalists do? J. Bus. Ventur., 1989, 4, 231-248.

14. Lerner, J., Venture capitalists and the oversight of private firms. J. Financ., 1995, 50(1), 301-318.

15. Sahlman, W. A., The structure and governance of venture-capital organizations. J. Financ. Econ., 1990, 27, 473-521.

16. Sapienza, H. J., When do venture capitalists add value? J. Bus. Ventur., 1992, 7, 9-27.

17. Sørensen, M., How smart is smart money? A two-sided matching model of venture capital. J. Financ., 2007, 62, 2725-2762.

18. Amit, R., Brander, J. and Zott, C., Why do venture capital firms exist? Theory and Canadian evidence. J. Bus. Ventur., 1998, 13, $441-446$. 
19. Chan, Y. S., On the positive role of financial intermediation in allocation of venture capital in a market with imperfect information. J. Financ., 1983, 38(5), 1543-1568.

20. Tyebjee, T. T. and Bruno, A. V., A model of venture capitalist investment activity. Manage. Sci., 1984, 30, 1051-1066.

21. Admati, A. R. and Pfleiderer, P., Robust financial contracting and the role of venture capitalists. J. Financ., 1994, 49, 371402.

22. Kaplan, S. and Strömberg, P., Financial contracting theory meets the real world: evidence from venture capital contracts. Rev. Econ. Stud., 2003, 70(2), 281-315.

23. Mitchell, F., Reid, G. C. and Terry, N. G., Venture capital supply and accounting information system development. Entrep. Theory Pract., 1997, 21, 45-62.

24. Megginson, W. L. and Weiss, K. A., Venture capitalist certification in initial public offerings. J. Financ., 1991, 46, 879903.

25. Harrison, R. T. and Mason, C. M., Annual Report on the Business Angel Market in the United Kingdom, 2008/09, June 2010.

26. Sohl, J. E., The early stage equity market in the United States. Venture Capital: Int. J. Entrepren. Fin., 1999, 1, 101-120.

27. Kerr, W. R., Lerner, J. and Schoar, A., The consequences of entrepreneurial finance: a regression discontinuity analysis. Rev. Financ. Stud., 2014, 27, 20-55.

28. Capizzi, V., The returns of business angel investments and their major determinants. Venture Capital: An International Journal of Entrepreneurial Finance, 2015. 17(4), 271-298.

29. Lerner, J., Schoar, A., Sokolinski, S. and Wilson, K., The globalization of angel investments: evidence across countries. HBS Working Paper, 2016, 16-072.

30. Levratto, N., Tessier, L. and Fonrounge, C., Business performance and angels presence: a fresh look from France 2008-2011. Small Bus. Econ. Group, 2018, 50(2), 339-356.

31. Hellman, T., Schure, P. and Vo, D., Angel and venture capitalists: complements or substitutes? NBER Working Paper, 2013.

32. Mason, C. M., Botelho, T. and Harrison, R. T., The transformation of the business angel market: empirical evidence and research implications. Venture Capital: Int. J. Entrepren. Fin., 2016, 19(4), $321-344$.

33. Tuomi, K. and Harrison, R. T., A comparison of equity crowdfounding in four countries: Implications for business angels. Strat. Change, 2017, 26(6), 609-615.

34. Ahlers, G. K., Cumming, D., Günther, C. and Schweizer, D., Signaling in equity crowdfunding. Entrep. Theory Pract., 2015, 39, 955-980.

35. Agrawal, A., Catalini, C. and Goldfarb, A., Are syndicates the killer app of equity crowdfunding? Calif. Manage. Rev., 2016, 58, 111124

36. Allison, T. H., Davis, B. C., Short, J. C. and Webb, J. W., Crowdfunding in a prosocial microlending environment: examining the role of intrinsic versus extrinsic cues. Entrep. Theory Pract., 2015, 39, 53-73.

37. Vulkan, N., Åstebro, T. and Sierra, M. F., Equity crowdfunding: a new phenomena. J. Bus. Ventur. Insights, 2016, 5, 37-49.

38. Cumming, D. J. and Vismara, S., De-segmenting research in entrepreneurial finance. Venture Capital: Int. J. Entrepren. Fin., 2017, 19(1/2), 17-27.

39. de Bellis, N., Bibliometrics and Citation Analysis: From the Science Citation Index to Cybermetrics, Scarecrow Press, Lanham, MD, 2009.

40. Cobo, M. J., López-Herrera, A. G., Herrera-Viedma, E. and Herrera, F., Science mapping software tools: review, analysis, and cooperative study among tools. J. Am. Soc. Inf. Sci. Technol., 2011, 62(7), 1382-1402.

41. Cadavid-Higuita, L., Awad, G. and Franco-Cardona, C., Un análisis bibliométrico de un campo de modelado para la difusión de la innovación. Estudios Gerenciales, 2012, 28, 213-236.
42. Castillo-Vergara, M., Alvarez-Marin, A. and Placencio-Hidalgo, D., A bibliometric analysis of creativity in the field of business economics. J. Bus. Res., 2018, 85, 1-9.

43. Waltman, L. and Van Eck, N., A new methodology for constructing a publication level classification system of science. J. Am. Soc. Inf. Sci. Technol., 2012, 63, 2378-2392.

44. Cobo, M., López-Herrera, A., Herrera-Viedma, E. and Herrera, F., SciMAT: A new science mapping analysis software tool. J. Am. Soc. Inf. Sci. Technol., 2012, 63, 1609-1630.

45. Callon, M., Courtial, J.-P. and Laville, F., Coword analysis as a tool for describing the network of interactions between basic and technological research: the case of polymer chemistry. Scientometrics, 1991, 22(1), 155-205.

46. Engel, D. and Stiebale, J., Private equity, investment and financial constraints : firm-level evidence for France and the United Kingdom. Small Bus. Econ. Group, 2014, 43(1), 197-212.

47. Kortum, S. and Lerner, J., Assessing the contribution of venture capital to innovation. Rand J. Econ., 2000, 31, 674-692.

48. Hellmann, T. and Puri, M., The interaction between product market and financing strategy: the role of venture capital. Rev. Financ. Stud., 2000, 13, 959-984.

49. Engel, D. and Keilbach, M., Firm-level implications of early stage venture capital investment - an empirical investigation. J. Empir. Financ., 2007, 14(2), 150-167.

50. Chemmanur, T. J., Krishnan, K. and Nandy, D. K., How does venture capital financing improve efficiency in private firms? A look beneath the surface. Rev. Financ. Stud., 2011, 24(617), 40374090.

51. Croce, A., Martí, J. and Murtinu, S., The impact of venture capital on the productivity growth of European entrepreneurial firms: 'screening' or 'value added' effect? J. Bus. Ventur., 2013, 28(4), 489-510.

52. Bertoni, F., Colombo, M. G. and Grilli, L., Venture capital financing and the growth of high-tech start-ups: disentangling treatment from selection effects. Res. Policy, 2011, 40(7), 1028-1043.

53. Davila, A., Foster, G. and Gupta, M., Venture capital financing and the growth of startup firms. J. Bus. Ventur., 2003, 18(6), 689708.

54. Grilli, L. and Murtinu, S., Government, venture capital and the growth of European high-tech entrepreneurial firms. Res. Policy, 2014, 43(9), 1523-1543.

55. Paglia, J. K. and Harjoto, M. A., The effects of private equity and venture capital on sales and employment growth in small and medium-sized businesses. J. Bank Financ., 2014, 47(1), 177-197.

56. Puri, M. and Zarutskie, R., On the life cycle dynamics of venturecapital- and non-venture-capital-financed firms. J. Financ., 2012, 67(6), 2247-2293.

57. Barry, C. B., Muscarella, C. J., Peavy III, J. W. and Vetsuypens, M. R., The role of venture capital in the creation of public companies: evidence from the going public process. J. Financ. Econ., 1990, 27, 447-471.

58. Stuart, T. E., Hoang, H. and Hybels, R. C., Interorganizational endorsements and the performance of entrepreneurial ventures. Adm. Sci. Q., 1999, 44(2), 315-349.

59. Mason, C. and Stark, M., What do investors look for in a business plan?: a comparison of the investment criteria of bankers, venture capitalists and business angels. Int. Small Bus. J., 2004, 22(3), 227-248.

60. Croce, A., Tenca, F. and Ughetto, T., How business angel groups work: Rejection criteria in investment evaluation. Int. Small Bus. $J .$, 2017, 35(4), 405-426.

61. Mason, C. M., Botelho, T. and Zygmunt, J., Why business angels reject investment opportunities: is it personal? Int. Small Bus. J., 2017, 35(5), 519-534.

62. Mason, C. M. and Harrison, R. T., Business angel investment activity in the financial crisis: UK evidence and policy implications. Environ. Plan. C-Gov. Policy, 2015, 33(1), 43-60. 
63. Dutta, S. and Folta, T. B., A comparison of the effect of angels and venture capitalists on innovation and value creation. J. Bus. Ventur., 2016, 31, 39-54.

64. Sorenson, O. and Stuart, T. E., Syndication networks and the spatial distribution of venture capital investments. Am. J. Sociol., 2001, 106(6), 1546-1588.

65. Hockberg, Y. U., Ljungqvist, A. and Lu, Y., Whom you know matters: venture capital networks and investment performance. J. Financ., 2007, LXII(1), 251-301.

66. Lockett, A. and Wright, M., The syndication of venture capital investments. Omega, 2001, 29, 175-190.

67. Manigart, S. et al., Venture capitalists' decision to syndicate. Entrep. Theory Pract., 2006, 30, 131-153.

68. Zhang, A. Y., Access to venture capital and the performance of venture-backed start-ups in silicon valley. Econ. Dev. Q., 2007, 21(2), 124-147.

69. Gompers, P. and Josh Lerner, J., The determinants of corporate venture capital success: organizational structure, incentives and complementarities. NBER Working Paper, 1998, 6725.

70. Gans, J. S. and Stern, S., The product market and the market for 'ideas': commercialization strategies for technology entrepreneurs. Res. Policy, 2003, 32(2), 333-350.

71. Dushnitsky, G. and Lenox, M. J., When does corporate venture capital investment create firm value? J. Bus. Ventur., 2006, 21, 753-772.

72. Wadhwa, A. and Kotha, S., Knowledge creation through external venturing: evidence from the telecommunications equipment manufacturing industry. Acad. Manage. J., 2006, 49, 819-835.

73. Allen, S. A. and Hevert, K. T., Venture capital investing by information technology companies: did it pay? J. Bus. Ventur., 2007, 22, 262-282.
74. Cumming, D. J. and Zhang, M., Angel investors around the world. J. Int. Bus. Stud., 2018; https://doi.org/10.1057/s41267-018-0178-0

75. Huang, L. and Pearce, J. L., Managing the unknowable: The effectiveness of early-stage investor gut feel in entrepreneurial investment decisions. Adm. Sci. Q., 2015, 60, 634-670.

76. Harrison, R. T. and Mason, C. M., Backing the horse or the jockey? due diligence, agency costs, information and the evaluation of risk by business angel investors. Int. Rev. Entrepren., 2017, 15(3), 269-290.

77. Block, J., Hornuf, L. and Moritz, A., Which updates during an equity crowdfunding campaign increase crowd participation? Small Bus. Econ. Group, 2018, 50(1), 3-27.

78. Hornuf, L. and Schwienbacher, A., Market mechanisms and funding dynamics in equity crowdfunding. J. Corp. Financ., 2018, 50, 556-574.

79. Brown, R., Mawson, S., Rowe, A. and Mason, C., Working the crowd: Improvisational entrepreneurship and equity crowdfunding in nascent entrepreneurial ventures. Int. Small Bus. J., 2018, 36(2), 169-193.

80. Drover, W., Wood, M. and Zacharakis, A., Attributes of angel and crowd funded ventures as determinants of VC screening decisions. Entrep. Theory Pract., 2017, 41(3), 323-347.

ACKNOWLEDGEMENT. We acknowledge financial assistance from the Spanish Ministry of Economics and Competitiveness (ECO201455674-R).

Received 6 August 2018; revised accepted 23 October 2018

doi: $10.18520 /$ cs/v116/i6/926-935 